\title{
The Role of Aspirin in the Prevention of Cardiovascular Disease
}

\author{
Sunitha V. Ittaman, MD; Jeffrey J. VanWormer, PhD; and Shereif H. Rezkalla, MD
}

\begin{abstract}
Aspirin therapy is well-accepted as an agent for the secondary prevention of cardiovascular events and current guidelines also define a role for aspirin in primary prevention. In this review, we describe the seminal trials of aspirin use in the context of current guidelines, discuss factors that may influence the effectiveness of aspirin therapy for cardiovascular disease prevention, and briefly examine patterns of use. The body of evidence supports a role for aspirin in both secondary and primary prevention of cardiovascular events in selected population groups, but practice patterns may be suboptimal. As a simple and inexpensive prophylactic measure for cardiovascular disease, aspirin use should be carefully considered in all at-risk adult patients, and further measures, including patient education, are necessary to ensure its proper use.
\end{abstract}

Keywords: Non-steroidal anti-inflammatory agents; Aspirin/history/therapeutic use; Cardiovascular diseases/drug therapy; Coronary artery disease

\begin{abstract}
A 2007, the Agen (AHRQ) reported that nearly $20 \%$ of adults in the United States reported taking aspirin daily or every other day, with this number increasing to nearly $50 \%$ in those aged 65 and older. ${ }^{1}$ Aspirin is also one of the oldest drugs in use, with a history dating back to the period of Hippocrates and Galen, when the bark of the willow tree was famous for its analgesic and anti-inflammatory properties. Records show its widespread use by ancient Mesopotamian, Greek, and Chinese civilizations. In 1758, in the first recorded clinical trial in history, Reverend Edward Stone of the Royal Society of London demonstrated the efficacy of ground, dried bark from the English willow tree for treating the symptoms of malaria. However, aspirin as we know it today was not introduced for public use until 1904, following a series of attempts at extraction and purification of salicylic acid from willow bark and subsequent modification to acetylsalicylic acid to reduce the unpleasant side effects. ${ }^{2}$ In addition to its
\end{abstract}

Corresponding Author: Shereif Rezkall MD, FACP. Department of Cardiology; Marshfield Clinic; 1000 N Oak Ave; Marshfield, WI 54449; Tel: (7I5) 387-5845; Fax: (7I5) 389-5757; Email: rezkalla.shereif@ marshfieldclinic.org anti-inflammatory properties, aspirin was also observed to increase bleeding time, and later studies demonstrated the utility of aspirin as an anti-thrombotic agent. ${ }^{3}$

It was not until 1971 that aspirin's exact pharmacological mechanism of action of irreversible cyclooxygenase (COX) inhibition and related suppression of prostaglandin production was discovered. Later studies demonstrated that the antithrombotic effects of aspirin were the result of acetylation of COX in platelets. ${ }^{3}$ Low-dose aspirin regimens $(\geq 30 \mathrm{mg} /$ day) can effectively suppress platelet aggregation without affecting important endothelial cell functions. ${ }^{4}$ In contrast, inhibition of inflammatory cell function requires higher, more frequent dosing. ${ }^{2}$ The major drawback to continuous aspirin use is the risk of major gastrointestinal, and more rarely, intracranial bleeding, that can occur at any dose. Other side effects, such as hypertension and gastrointestinal or renal toxicity, are usually dose-related. 
Table 1. Summary of trials evaluating aspirin for primary prevention of serious cardiovascular events.

\begin{tabular}{|c|c|c|c|c|c|c|c|c|c|}
\hline Trial & $\mathrm{BDT}^{16}$ & PHS ${ }^{17}$ & TPT $^{18}$ & HOT $^{19}$ & PPP $^{20}$ & WHS $^{21}$ & POPADAD $^{22}$ & JPAD $^{23}$ & AAA $^{24}$ \\
\hline Country & United Kingdom & Unites States & United Kingdom & Multinational & Italy & United Stated & Scotland & Japan & United Kingdom \\
\hline Year & 1988 & 1989 & 1998 & 1998 & 2001 & 2005 & 2008 & 2008 & 2010 \\
\hline Study design & $\begin{array}{l}\text { Randomized, } \\
\text { open label }\end{array}$ & $\begin{array}{l}\text { Randomized, } \\
\text { double blind, } \\
\text { placebo } \\
\text { controlled }\end{array}$ & $\begin{array}{c}\text { Factorial, double } \\
\text { blind, placebo } \\
\text { controlled }\end{array}$ & $\begin{array}{l}\text { Factorial, } \\
\text { double blind, } \\
\text { placebo } \\
\text { controlled }\end{array}$ & $\begin{array}{l}\text { Randomized, } \\
\text { open label, } 2 \times 2 \\
\text { factorial }\end{array}$ & $\begin{array}{l}\text { Randomized, } \\
\text { double blind, } \\
\text { placebo } \\
\text { controlled }\end{array}$ & $\begin{array}{l}\text { Randomized, } \\
\text { double blind, } \\
\text { placebo } \\
\text { controlled }\end{array}$ & $\begin{array}{l}\text { Randomized, } \\
\text { open label }\end{array}$ & $\begin{array}{l}\text { Randomized, } \\
\text { double blind, } \\
\text { placebo } \\
\text { controlled }\end{array}$ \\
\hline Number of patients & 5,139 & 22,071 & 5,085 & 18,790 & 4,495 & 39,876 & 1,276 & 2,539 & 3,350 \\
\hline Number of women & 0 & 0 & 0 & 8,883 & 2,583 & 39,876 & 713 & 1,153 & 2,412 \\
\hline Aspirin dose & 500 mg/day & $\begin{array}{c}325 \mathrm{mg} \text { every } \\
\text { other day }\end{array}$ & 75 mg/day & 75 mg/day & 100 mg/day & $\begin{array}{l}100 \mathrm{mg} \text { every } \\
\text { other day }\end{array}$ & 100 mg/day & $\begin{array}{c}81 \text { or } 100 \\
\mathrm{mg} / \text { day }\end{array}$ & 100 mg/day \\
\hline Duration of therapy & 5.8 years & 5 years & 6.8 years & 3.8 years & 3.6 years & 10.1 years & 6.7 years & 4.4 years & 8.2 years \\
\hline \multicolumn{10}{|l|}{ Risk in aspirin group } \\
\hline Any CV event & NS & NR & NR & $\begin{array}{c}\mathrm{RR}=0.85 \\
(95 \% \mathrm{Cl} 0.73- \\
0.99)\end{array}$ & $\begin{array}{c}\mathrm{RR}=0.77 \\
(95 \% \mathrm{Cl} 0.62 \\
-0.95)\end{array}$ & $\begin{array}{c}\mathrm{RR}=0.91 \\
(95 \% \mathrm{Cl} 0.80- \\
1.03)\end{array}$ & $\begin{array}{c}\mathrm{HR}=0.98 \\
(95 \% \mathrm{Cl} 0.76- \\
1.26)\end{array}$ & $\begin{array}{c}\mathrm{HR}=0.80 \\
(95 \% \mathrm{Cl} 0.58- \\
1.10)\end{array}$ & $\begin{array}{c}\mathrm{HR}=1.03 \\
(95 \% \mathrm{Cl} 0.87- \\
1.27)\end{array}$ \\
\hline $\mathrm{Ml}$ & NS & $\begin{array}{c}\mathrm{RR}=0.56 \\
(95 \% \mathrm{Cl} 0.45- \\
0.70)\end{array}$ & $\begin{array}{l}20 \% \text { reduction } \\
(95 \% \text { Cl 1-35) }\end{array}$ & $\begin{array}{c}\mathrm{RR}=0.64 \\
(95 \% \mathrm{Cl} 0.49- \\
0.85)\end{array}$ & $\begin{array}{c}\mathrm{RR}=0.69 \\
(95 \% \mathrm{Cl} 0.38- \\
1.23)\end{array}$ & $\begin{array}{c}\mathrm{RR}=1.02 \\
(95 \% \mathrm{Cl} 0.84- \\
1.25)\end{array}$ & NS & $\begin{array}{c}\mathrm{HR}=0.81 \\
(95 \% \mathrm{Cl} 0.49- \\
1.33)\end{array}$ & NS \\
\hline Stroke & NS & $\begin{array}{c}\mathrm{RR}=1.22(95 \% \\
\mathrm{Cl} 0.93-1.60)\end{array}$ & $\begin{array}{c}3 \% \text { reduction } \\
(95 \% \mathrm{Cl}-45-35)\end{array}$ & $\begin{array}{c}\mathrm{RR}=0.88 \\
(955 \mathrm{Cl} 0.78- \\
1.24)\end{array}$ & $\begin{array}{c}\mathrm{RR}=0.67 \\
(95 \% \mathrm{Cl} 0.36- \\
1.27)\end{array}$ & $\begin{array}{c}\mathrm{RR}=0.83 \\
(95 \% \mathrm{Cl} 0.69- \\
0.99)\end{array}$ & NS & $\begin{array}{c}\mathrm{HR}=0.84 \\
(95 \% \mathrm{Cl} 0.53- \\
1.32)\end{array}$ & NS \\
\hline CV-specific mortality & y $6 \%$ decrease & $\begin{array}{c}\mathrm{RR}=0.96(95 \% \\
\mathrm{Cl} 0.60-1.54)\end{array}$ & NR & $\begin{array}{c}\mathrm{RR}=0.95 \\
(95 \% \mathrm{Cl} 0.75- \\
1.20)\end{array}$ & $\begin{array}{c}\mathrm{RR}=0.56 \\
(95 \% \mathrm{Cl} 0.31- \\
0.99)\end{array}$ & $\begin{array}{c}\mathrm{RR}=0.95 \\
(95 \% \mathrm{Cl} 0.74- \\
1.22)\end{array}$ & $\begin{array}{c}\mathrm{HR}=1.23 \\
(95 \% \mathrm{Cl} 0.79- \\
1.93)\end{array}$ & $\begin{array}{c}\mathrm{HR}=0.10 \\
(95 \% \mathrm{Cl} 0.01- \\
0.79)\end{array}$ & NR \\
\hline All-cause mortality & NS & $\begin{array}{c}\mathrm{RR}=0.95(95 \% \\
\mathrm{Cl} 0.79-1.15)\end{array}$ & $\begin{array}{c}6 \% \text { increase } \\
(95 \% \mathrm{Cl}-28-12)\end{array}$ & $\begin{array}{c}\mathrm{RR}=0.93 \\
(95 \% \mathrm{Cl} 0.79- \\
1.09)\end{array}$ & $\begin{array}{c}\mathrm{RR}=0.81 \\
(95 \% \mathrm{Cl} 0.58- \\
1.13)\end{array}$ & $\begin{array}{c}\mathrm{RR}=0.95 \\
(95 \% \mathrm{Cl} 0.85- \\
1.06)\end{array}$ & $\begin{array}{c}\mathrm{HR}=0.93 \\
(95 \% \mathrm{Cl} 0.71- \\
1.24)\end{array}$ & $\begin{array}{c}H R=0.90 \\
(95 \% \mathrm{Cl} 0.57- \\
1.14)\end{array}$ & $\begin{array}{c}H R=0.95 \\
(95 \% \mathrm{Cl} 0.77- \\
1.16)\end{array}$ \\
\hline
\end{tabular}

BDT, British Doctors' Trial; PHS, Physicians' health Study; TPT, thrombosis prevention trial; HOT, hypertension optimal treatment; PPP, Primary Prevention Project; WHS, Women's Health Study; POPADAD, Prevention of Progression of Arterial Disease and Diabetes; JPAD, Japanese Primary Prevention of Atherosclerosis with Aspirin for Diabetes; AAA, Aspirin for Asymptomatic Atherosclerosis; CV, cardiovascular; MI, myocardial infarction; NS, not significant; NR, not reported; RR, relative risk; HR, hazard ratio; $\mathrm{Cl}$, confidence interval

The use of a low-dose aspirin regimen as an anti-thrombotic measure has become increasingly common. However, recent evidence suggests discrepancies exist between clinical guidelines for the use of aspirin therapy for primary and secondary cardiovascular disease (CVD) prevention and actual patient use patterns. ${ }^{5,6}$ Here we review and describe the literature to support the use of aspirin for primary and secondary CVD prevention, as well as the role of clinical guidelines in patient and physician practices.

\section{Aspirin in Secondary Prevention}

Patients who suffer from one or more CVD events, such as myocardial infarction (MI) or ischemic stroke, are at very high risk for another CVD event. While rescue procedures, such as percutaneous coronary intervention (PCI), are aimed at stabilizing acute events, aspirin therapy may actually serve to prevent subsequent CVD events. The role of aspirin in reducing CVD mortality and repeat events after acute MI was first demonstrated in the second International Study of Infarct Survival (ISIS-2) trial. ${ }^{7}$ In this study, 17,187 patients from 417 hospitals were enrolled within 24 hours after onset of suspected acute MI and randomized to receive: (i) a 1-hour intravenous infusion of 1.5 MU of streptokinase; (ii) one month of $160 \mathrm{mg}$ /day enteric-coated aspirin; (iii) both treatments; or (iv) neither. Aspirin use resulted in a significant reduction in non-fatal reinfarction, stroke, 5-week vascular mortality, and all-cause mortality. ${ }^{7}$ Although other, smaller trials showed similar benefits for patients with a history of previous MI, the ISIS- 2 trial was the first to provide evidence of a direct effect of aspirin on acute MI, demonstrating that one month of low-dose aspirin started immediately after MI in 1000 patients would prevent 25 deaths and 10 to 15 nonfatal infarcts and strokes. Additional mortality benefits were observed with longer duration of aspirin therapy. ${ }^{7}$

Since the ISIS-2 trial, many other groups have demonstrated similar results when aspirin is used for secondary prevention of CVD events. In 2002, the Antithrombotic Trialists' Collaboration analyzed 16 trials of long-term aspirin use with doses ranging from $50-1500 \mathrm{mg} /$ day for secondary prevention of CVD events, including over 17,000 subjects and 3,306 serious vascular events. ${ }^{8}$ In these trials, aspirin use resulted in significant reductions in serious vascular events including stroke and coronary events in both men and women and low dose regimens $(75-100 \mathrm{mg} /$ day $)$ were found to be as effective as higher doses. ${ }^{8}$ Aspirin use as a secondary prevention measure for serious CVD events is well-accepted and recommended by several major organizations..$^{9-13}$ 


\section{Aspirin in Primary Prevention}

Secondary prevention following a serious CVD event is necessitated by the high risk for a repeat event. However, initial CVD events can be fatal or disabling, making primary prevention an important consideration as well. ${ }^{14}$ The notion that aspirin could be used for primary CVD prevention existed before its well-established use for secondary prevention. More than half a century ago, Dr. Lawrence Craven introduced the concept of aspirin therapy for primary prevention of MI and frequently recommended aspirin therapy to his patients. ${ }^{3}$ Dr. Craven worked as a general practitioner at the Glendale Memorial Hospital in California and was fascinated by the etiology of MI. Noting an increased risk of bleeding in patients who received aspirin gums for pain relief after tonsillectomy, Craven hypothesized that aspirin's antithrombotic properties would be beneficial for preventing MI. Craven conducted informal clinical trials of aspirin for prevention of MI with positive outcomes and ultimately recommended aspirin for primary CVD prevention in males aged 45-65 years. It is interesting to note that Craven's recommendations are remarkably similar to the present guidelines for the use of aspirin in primary CVD prevention. Since Craven's early descriptions, several major trials have examined the use of aspirin for primary prevention, as outlined in table 1 . The role of aspirin for primary CVD prevention remains controversial, however, particularly in Europe, due largely to the potential for major bleeding as an adverse effect. ${ }^{15}$

In the last 30 years, nine major trials have examined the benefit of aspirin for primary CVD prevention, including the British Doctors' Trial, ${ }^{16}$ Physicians' Health Study, ${ }^{17}$ Thrombosis Prevention Trial, ${ }^{18}$ Hypertension Optimal Treatment, ${ }^{19}$ Primary Prevention Projects, ${ }^{20}$ Women's Health Study ${ }^{21}$ Prevention of Progression of Arterial Disease and Diabetes, ${ }^{22}$ Japanese Primary Prevention of Atherosclerosis, ${ }^{23}$ and Aspirin for Asymptomatic Atherosclerosis ${ }^{24}$ trials (table 1). Trial results were published between 1988 and 2010 and included a mix of healthy subjects and subjects with elevated CVD risk based on signs of underlying atherosclerotic disease or the presence of diabetes mellitus. Aspirin doses ranged from $50 \mathrm{mg}$ to $650 \mathrm{mg}$ per day, with all trials after 1998 prescribing $100 \mathrm{mg}$ or less. Trial results were mixed to some degree, but the preponderance of evidence suggested that aspirin could decrease CVD risk, ${ }^{19,20}$ including MI $^{17-19}$ and stroke. ${ }^{21}$ When cardiovascular and all-cause mortality was assessed, no statistically significant effect on all-cause mortality was observed, but the Primary Prevention Project and Japanese Primary Prevention of Atherosclerosis trials noted a significant reduction in cardiovascular-specific mortality secondary to regular aspirin use of $100 \mathrm{mg} /$ day. ${ }^{20,23}$

Several meta-analyses have been conducted to evaluate the collective outcomes of the studies described above. Three recent meta-analyses examined the effects of aspirin on risk of any serious cardiovascular event, myocardial infarction, stroke, cardiovascular-specific mortality, and all-cause mortality in the more than 100,000 subjects included in the nine major trials described above. Bartolucci et al, ${ }^{25}$ Berger et $\mathrm{al}^{26}$ and Seshasai et $\mathrm{al}^{27}$ found a significant decrease in the risk of serious cardiovascular events, including nonfatal myocardial infarction, stroke, or cardiovascular death, with use of aspirin. Odds ratios (ORs) ranged from 0.85 (95\% CI $0.79-0.92)$ to $0.90(95 \%$ CI $0.85-0.96)$. Seshasai et al ${ }^{27}$ also demonstrated an overall reduction in all-cause mortality ( $\mathrm{OR}=0.84,95 \%$ CI $0.88-1.00)$, but this was not observed in the other two meta-analyses. ${ }^{25,26}$ Despite the apparent benefits of aspirin therapy for primary CVD prevention, some metaanalyses suggest that the benefits may be outweighed by the risk of major bleeding. ${ }^{26,27,28}$

Several groups have investigated possible solutions for maintaining the benefits of aspirin therapy while reducing the risk for bleeding. In a 2009 meta-analysis, the Antithrombotic Trialists' Collaboration examined six primary prevention trials including over 95,000 subjects. ${ }^{28}$ Interestingly and unfortunately, the main risk factors for CVD were similar to those for major bleeding. ${ }^{28}$ To ameliorate the risk of gastrointestinal bleeding, several groups demonstrated the utility of co-administration of a proton-pump inhibitor, ${ }^{29-31}$ which was later recommended concurrent with aspirin in those at high-risk for ulcer bleeding. ${ }^{32,33}$ Others hypothesized that aspirin could be replaced with another anti-thrombotic agent to reduce CVD risk while eliminating the bleeding risk. However, in two prospective clinical trials, Chan et $\mathrm{al}^{34}$ and Lai et $\mathrm{a}^{35}$ demonstrated that the combination of aspirin and esomeprazole was superior to clopidogrel for the prevention of recurrent ulcer bleeding. Despite its inferiority as an agent for prevention of CVD, clopidogrel can be considered in eligible patients with a mild intolerance to aspirin.

A recent study by Brighton et $\mathrm{al}^{36}$ showed no reduction in recurrent thromboembolic events with aspirin use of $100 \mathrm{mg} /$ day, but there was a clear reduction in the occurrence of other serious cardiovascular events by $34 \%(P=0.01)$ compared to the placebo group. In addition, no differences in bleeding or other serious adverse events were observed. ${ }^{36}$ Despite the relatively small reduction in mortality demonstrated in trials of aspirin for primary CVD prevention, there is a clear reduction in the risk of incident CVD events and several organizations, including the American Heart Association (AHA), the American College of Chest Physicians, the U.S. Preventative Task Force (USPSTF), and the European Society of Cardiology (ESC), have concluded that aspirin is beneficial and safe for primary CVD prevention when used properly. ${ }^{15}$ Considering the conflicting data, physicians must be cognizant of their role in assessing the potential for benefit and subsequent risk of bleeding in individual patients prior to making recommendations.

\section{Aspirin and Gender Differences}

Well known differences exist in the epidemiology of vascular events in men and women. Men are more prone to stroke and MI, yet women are more likely to die from these events than 
men. ${ }^{12}$ Similarly, meta-analysis results suggest that there are also gender differences in the effects of aspirin on CVD, whereby risk of $\mathrm{MI}$ appears to be reduced in men and risk of stroke appears to be reduced in women. ${ }^{28,37}$ Current guidelines for the use of aspirin for CVD prevention take these differences into consideration. Aspirin use in males is primarily intended for the prevention of coronary artery disease, while in females, prevention of stroke is the main target. ${ }^{12}$ The reason for differences in the effect of aspirin therapy by gender is currently unknown, but evidence suggests that there may be some biological basis for these differences. For example, baseline platelet reactivity is greater in women than in men, with higher residual reactivity following aspirin treatment in women. ${ }^{38}$ As such, physicians should also be sure to consider gender-specific risks, benefits, and guidelines for aspirin therapy prior to making patient recommendations.

\section{Aspirin and Diabetes}

Much of the ongoing controversy regarding the utility of aspirin for prevention of cardiovascular disease surrounds use in patients with diabetes. Individuals with diabetes have a 2-4 fold increased risk for serious cardiovascular events as a result of increased coronary thrombus formation, increased platelet reactivity, and worsened endothelial dysfunction. ${ }^{39}$ Few of the early studies on aspirin focused specifically on patients with diabetes. The Early Treatment Diabetic Retinopathy Study included patients with type 1 and 2 diabetes mellitus and some degree of retinopathy. ${ }^{40}$ Cardiovascular outcomes were compared in patients given $650 \mathrm{mg}$ of aspirin daily versus placebo as a secondary study outcome. A significant reduction in fatal and nonfatal MI was observed in the aspirin group. ${ }^{41}$ Based on these findings, and findings from the above-mentioned trials, in 2007, the AHA and American Diabetes Association issued joint guidelines recommending aspirin as a primary prevention strategy in patients with diabetes at increased cardiovascular risk, including those over age 40 or with other risk factors such as family history of cardiovascular disease, hypertension, smoking, dyslipidemia, or albuminuria. ${ }^{42}$ However, later studies that focused on patients with diabetes exclusively, including the Prevention of Progression of Arterial Disease and Diabetes ${ }^{22}$ and Japanese Primary Prevention of Atherosclerosis With Aspirin for Diabetes ${ }^{23}$ studies, provided limited evidence for heart health benefits with aspirin use in patients with diabetes and no history of CVD. A 2010 metaanalysis by Zhang et $\mathrm{al}^{43}$ focused on the benefits and risks of aspirin therapy in patients with diabetes in seven trials involving 11,618 patients with diabetes and found no significant reduction in either serious cardiovascular events or all-cause mortality. However, sex-specific effects on MI and stroke were observed, consistent with previous studies. The meta-analysis authors hypothesize that the more neutral role of aspirin in this population may be the result of side effects, such as gastrointestinal bleeding and aspirin resistance. ${ }^{43}$ In light of these findings, the American Diabetes Association now recommends that low-dose aspirin be prescribed primarily for men over age 50 and women over age 60 who have diabetes and at least moderate CVD risk or who have had a previous MI or stroke. ${ }^{39}$ Given these guidelines and the findings described above, it is important for physicians to remember that, despite the increased risk for CVD in patients with diabetes, simply having diabetes does not qualify a patient for aspirin therapy. Physicians must still perform a proper cardiovascular and bleeding risk assessment before making patient recommendations.

\section{Ongoing Aspirin Trials}

Despite the widespread use of aspirin for CVD prevention and the recommendation for such treatment by many prominent medical organizations, regional controversies regarding aspirin use remain. ${ }^{15}$ For example, the Canadian Cardiovascular Society (CVS) maintains that the number of primary serious cardiovascular events prevented is offset by the risk of bleeding. ${ }^{10}$ An additional concern of the CVS is the age of the primary prevention trials, which occurred before the widespread use of other prevention therapies such as statins. ${ }^{10,17}$ As such, additional studies are currently ongoing including the Aspirin in Reducing Events in the Elderly (ASPREE) study, ${ }^{44}$ Aspirin and Simvastatin Combination for CV Events Prevention Trial in Diabetes (ACCEPT-D), ${ }^{45}$ and A Study of Cardiovascular Events in Diabetes (ASCEND). ${ }^{46}$ The ASPREE trial is being conducted jointly in the United States and Australia to compare use of low-dose aspirin to a placebo control in patients age 65 and older over a period of 5 years. $^{44}$ The ACCEPT-D trial is an Italian, open-label, primary prevention study comparing use of $100 \mathrm{mg}$ aspirin to no aspirin in patients over 50 years of age with diabetes and on simvastatin. ${ }^{45}$ The ASCEND trial is being conducted in the United Kingdom to compare use of $100 \mathrm{mg}$ aspirin/omega-3 fatty acid versus placebo control in men and women over age 40 with type 1 or 2 diabetes mellitus and no prior cardiovascular events. ${ }^{46}$ Most recently, the Aspirin to Reduce Risk of Initial Vascular Events trial began and is designed to examine the efficacy of low-dose aspirin for the prevention of several vascular events including fatal and nonfatal MI, stroke, and sudden cardiac death in men over age 50 and women over age 60 with no known congestive heart disease, but at moderate CVD risk. ${ }^{47}$ Physicians should be mindful of these ongoing trials and be ready to adapt practices if necessary pending outcomes, especially in patients on or who may benefit from combination therapy with aspirin and statins.

\section{Current Guidelines for Aspirin Use}

Nearly all major heart health organizations have made recommendations regarding aspirin use for CVD prevention, including the AHA/American Stroke Association, , $, 14,48$ American College of Chest Physicians (ACCP), ${ }^{13}$ USPSTF, ${ }^{12}$ $\mathrm{CVS},{ }^{10}$ and ESC. ${ }^{11}$ Organizational guidelines are in relative agreement for secondary prevention with life-long, low-dose aspirin therapy recommended following a CVD event. ${ }^{9-13}$ As previously intimated, however, the guidelines for primary CVD prevention are more variable (table 2). With the exception of the CVS, aspirin is generally recommended for 
Table 2. Recommendations for low-dose aspirin therapy.

\begin{tabular}{|c|c|c|}
\hline Organization & Primary Prevention & Secondary Prevention \\
\hline $\begin{array}{l}\text { American Heart Association/American } \\
\text { Stroke Association } \\
9,14,48\end{array}$ & $\begin{array}{l}\text { Recommended for persons whose } \\
\text { cardiovascular risk is sufficiently } \\
\text { high for the benefits to outweigh the } \\
\text { risks associated with treatment (10- } \\
\text { year risk of cardiovascular events } \\
\text { greater than } 6-10 \%) \text {. }\end{array}$ & $\begin{array}{l}\text { Heart attack and stroke survivors } \\
\text { are recommended to regularly take } \\
\text { low-dose aspirin for secondary } \\
\text { prevention. }\end{array}$ \\
\hline $\begin{array}{l}\text { American College of Chest } \\
\text { Physicians }^{13}\end{array}$ & $\begin{array}{l}\text { Recommended in all patients } \geq 50 \\
\text { years of age. }\end{array}$ & $\begin{array}{l}\text { Recommend use of low-dose aspirin } \\
\text { or clopidogrel for all patients with } \\
\text { established cardiovascular disease. }\end{array}$ \\
\hline U.S. Preventive Services Task Force ${ }^{12}$ & $\begin{array}{l}\text { Recommended for men ages } 45- \\
79 \text { when potential benefit due to } \\
\text { reduction in myocardial infarction } \\
\text { outweighs potential harm due to } \\
\text { increased bleeding. Recommended } \\
\text { for women ages } 55 \text { - } 79 \text { when } \\
\text { potential benefit due to reduction in } \\
\text { ischemic strokes outweighs the } \\
\text { potential harm due to increased } \\
\text { bleeding. }\end{array}$ & Same as primary prevention. \\
\hline Canadian Cardiovascular Society ${ }^{10}$ & $\begin{array}{l}\text { Use not recommended in men or } \\
\text { women without evidence of } \\
\text { manifest vascular disease. }\end{array}$ & $\begin{array}{l}\text { Recommend indefinite therapy with } \\
\text { low-dose aspirin for all patients } \\
\text { following a serious cardiovascular } \\
\text { event. }\end{array}$ \\
\hline European Society of Cardiology ${ }^{11}$ & $\begin{array}{l}\text { Recommended when the } 10 \text {-year } \\
\text { risk of cardiovascular mortality is } \\
\text { markedly increased and blood } \\
\text { pressure is controlled. }\end{array}$ & $\begin{array}{l}\text { Recommend life-long, low-dose } \\
\text { aspirin therapy in all patients with } \\
\text { established cardiovascular disease, } \\
\text { including those with diabetes, } \\
\text { unless contraindicated. }\end{array}$ \\
\hline
\end{tabular}

primary CVD prevention based on a given patient's underlying CVD risk profile. Difficulties arise when defining CVD risk, as many scoring systems and other metrics have been developed, but their availability and ease of used varies in different settings. ${ }^{15,49}$ For example, the AHA guidelines are based on the Framingham Risk Score, ${ }^{50}$ while the ESC uses the Systematic Coronary Risk Evaluation model for cardiovascular disease mortality. ${ }^{51}$ The USPSTF recently performed a systematic review of CVD risk assessment tools and found that patient characteristics, such as comorbid diabetes mellitus, also affect the validity of scoring systems. ${ }^{49}$ In contrast, the ACCP makes no stipulations regarding CVD risk, stating only that low dose aspirin therapy is recommended for persons $\geq 50$ years of age without symptomatic CVD, while recognizing that those who are averse to taking medication for a prolonged period of time for only small benefit are unlikely to use aspirin prophylactically. ${ }^{13}$

Despite certain inconsistences, all guidelines are clear that aspirin is inappropriate for patients with aspirin intolerance and those at increased risk of gastrointestinal bleeding or hemorrhagic stroke, which is usually evident from a previous history of such conditions. These aspirin contraindications are relatively uncommon, however, and the benefits of CVD risk reduction typically outweigh the bleeding risks for most patients at high CVD risk. Note that aspirin doses of $75 \mathrm{mg}$ to $162 \mathrm{mg}$ per day are typically better tolerated and are as effective as higher doses in conferring cardiovascular protection. ${ }^{14}$

Extensive review of the literature revealed a strong favor toward the use of low dose aspirin therapy for the primary prevention of CVD. While guidelines are somewhat controversial, several resources exist to help physicians make decisions with their patients. For example, the USPSTF guidelines provide a table that can help physicians assess risk versus benefit associated with aspirin use in primary prevention. ${ }^{12}$ Of note, a recent study showing evidence of a reduction in colon cancer mortality in patients attributable to low dose aspirin therapy is likely to result in additional allcause mortality benefits and to make a positive impact on patient and provider attitudes regarding aspirin use..$^{52}$

\section{Aspirin and Patient Use Patterns: Are We Using it the Right Way?}

Aspirin has been commercially available for over a century and used for antithrombotic purposes nearly as long. Despite clinical guidelines governing the use of aspirin for primary 
and secondary CVD prevention, evidence suggests that aspirin use remains suboptimal. In a meta-analysis of two studies examining use of low-dose aspirin therapy for secondary prevention, adherence was found to be approximately $65 \%(95 \%$ CI $53-77) .{ }^{5}$ Efforts to increase adherence to aspirin therapy for secondary prevention may therefore be worthwhile. Aspirin use patterns for primary CVD prevention may be even more troublesome. A recent study by VanWormer et $\mathrm{al}^{6}$ suggests that, across the population of Wisconsin adults without CVD or diabetes, aspirin is simultaneously underused by those at high CVD risk and overused by those at low CVD risk (per USPSTF guidelines). Specifically, among those clinically indicated for aspirin therapy, only $31 \%$ reported using aspirin regularly, whereas among those not clinically indicated for aspirin therapy, $18 \%$ reported regular aspirin use. These findings suggest that providers need to play a bigger role in educating patients, perhaps by becoming more aware of the evidence base themselves. Development of clinician-led programs to ensure that patients undergo regular screening for aspirin use may be not only beneficial to patient practices, ${ }^{6}$ but may also be relatively easy to implement in the era of widely-used electronic medical records (EMRs). Prompting in the EMR may remind physicians that low-dose aspirin is recommended for primary CVD prevention, ${ }^{12,14,48}$ but that individual risk factors as well as the risks and benefits associated with aspirin use should be considered on a case-by-case basis. In each case, patient education regarding both the potential benefits and harms of aspirin therapy should be given equal attention.

\section{Conclusion}

The benefit of low-dose aspirin therapy for the secondary prevention of serious cardiovascular events is clear, but the use of aspirin for the primary prevention of CVD remains challenging due to mixed findings on mortality benefit. ${ }^{10}$ Based on the available evidence, the USPSTF and AHA have put forth recommendations for the use of aspirin therapy in primary prevention with clearly delineated populations expected to benefit from use..$^{12,14,48}$ Despite the availability of evidence-based guidelines for aspirin therapy in both primary and secondary prevention populations (table 2), aspirin therapy is both underused ${ }^{5,6}$ and overused ${ }^{6}$ for reasons not yet understood. These could be related to patient beliefs ${ }^{53}$ or clinician preferences. Therefore, more research is needed in this area to optimize aspirin use in the groups most likely to benefit. Several trials are currently ongoing and may shed additional light on lingering concerns regarding the precise efficacy of aspirin therapy. In the interim, primary care physicians are urged to categorize their patients based on individual risk factors and to assess the risks and benefits associated with aspirin use on a case-by-case basis. ${ }^{6}$ The ability to prevent serious cardiovascular events and their associated sequelae with a single, inexpensive pill makes low-dose aspirin therapy worth considering.

\section{Acknowledgements}

The authors wish to acknowledge Rachel V. Stankowski, PhD of the Marshfield Clinic Research Foundation Office of Scientific Writing and Publishing for assistance with manuscript preparation.

\section{References}

1. Soni A. Aspirin use among the adult U.S. non institutionalized population, with and without indicators of heart disease, 2005. Statistical Brief \#129. Agency for Healthcare Research and Quality, Medical Expenditure Panel Survey. Available at: http://meps.ahrq.gov/mepsweb/data_files/publications/st179/ stat179.pdf. Accessed February 6, 2013.

2. Fuster V, Sweeny JM. Aspirin: a historical and contemporary therapeutic overview. Circulation 2011;123:768-778.

3. Miner J, Hoffhines A. The discovery of aspirin's antithrombotic effects. Tex Heart Inst J 2007;34:179-186.

4. Dippel DW, Van Kooten F, Leebeek FW, van Vilet HH, Mehicevic A, Li SS, Koudstaal PJ. What is the lowest dose of aspirin for maximum suppression of in vivo thromboxane production after a transient ischemic attack or ischemic stroke? Cerebrovasc Dis 2004;17:296-302.

5. Naderi SH, Bestwick JP, Wald DS. Adherence to drugs that prevent cardiovascular disease: a meta-analysis on 376,162 patients. Am J Med 2012;125:882-887.e1.

6. Vanwormer JJ, Greenlee RT, McBride PE, Peppard PE, Malecki $\mathrm{KC}$, Che J, Nieto FJ. Aspirin for primary prevention of CVD: are the right people using it? J Fam Pract 2012;61:525533.

7. ISIS-2 (Second International Study of Infarct Survival) Collaborative Group. Randomised trial of intravenous streptokinase, oral aspirin, both, or neither among 17,187 cases of suspected acute myocardial infarction: ISIS-2. Lancet 1988;2:349-360.

8. Antithrombotic Trialists' Collaboration. Collaborative metaanalysis of randomised trials of antiplatelet therapy for prevention of death, myocardial infarction, and stroke in high risk patients. BMJ 2002;324:71-86.

9. American Heart Association Website. Aspirin and Heart Disease. Available at: www.hert.org/HEARTORG/Condition/ HeartAttack/PreventionTreatmentofHeartAttack/Aspirin-andHeart-Disease_UCM_321714_Article.jsp. Accessed March 14, 2013.

10. Bell AD, Roussin A, Cartier R, Chan WS, Douketis JD, Gupta A, Kraw ME, Lindsay TF, Love MP, Pannu N, RabasaLhoret R, Shuaib A, Teal P, Théroux P, Turpie AG, Welsh $\mathrm{RC}$, Tanguay JF. The use of antiplatelet therapy in the outpatient setting: Canadian Cardiovascular Society Guidelines Executive Summary. Can J Cardiol 2011;27:208221.

11. Graham I, Atar D, Borch-Johnson K, Boysen G, Burell G, Cifkova R, Dallongeville J, De Backer G, Ebrahim S, Gjelsvik B, Herrmann-Lingen C, Hoes A, Humphries S, Knapton M, Perk J, Priori SG, Pyorala K, Reiner Z, Ruilope L, Sans-Menendez S, Op Reimer WS, Weissberg P, Wood D, Yarnell J, Zamorano JL; ESC Committee for Practice Guidelines. European guidelines on cardiovascular disease prevention in clinical practice: executive summary. Atherosclerosis 2007;194:1-45.

12. US Preventive Services Task Force. Aspirin for the prevention of cardiovascular disease: U.S. Preventive Services Task Force recommendation statement. Ann Intern Med 2009;150:396-404. 
13. Vandvik PO, Lincoff AM, Core JM, Gutterman DD, Sonnenberg FA, Alonso-Coello P, Akl EA, Lansberg MG, Guyatt GH, Spencer FA; American College of Chest Physicians. Primary and secondary prevention of cardiovascular disease: Antithrombotic Therapy and Prevention of Thrombosis, 9th ed: American College of Chest Physicians Evidence-Based Clinical Practice Guidelines. Chest 2012;141:e637S-e668S.

14. Pearson TA, Blair SN, Daniels SR, Eckel RH, Fair JM, Fortmann SP, Franklin BA, Goldstein LB, Greenland P, Grundy SM, Hong Y, Miller NH, Lauer RM, Ockene IS, Sacco RL, Sallis JF Jr, Stone NJ, Taubert KA. AHA guidelines for primary prevention of cardiovascular disease and stroke: 2002 update: consensus panel guide to comprehensive risk reduction for adult patients without coronary or other atherosclerotic vascular diseases. American Heart Association Science Advisory and Coordinating Committee. Circulation 2002;106:388-391.

15. Nemerovski CW, Salinitri FD, Morbitzer KA, Moser LR. Aspirin for primary prevention of cardiovascular disease events. Pharmacotherapy 2012;32:1020-1035.

16. Peto R, Gray R, Collins R, Wheatley K, Hennekens C, Jamrozik K, Warlow C, Hafner B, Thompson E, Norton S, Gilliland J, Doll R. Randomised trial of prophylactic daily aspirin in British male doctors. Br Med J (Clin Res Ed) 1988;296:313-316.

17. Steering Committee of the Physicians' Health Study Research Group. Final report on the aspirin component of the ongoing Physicians' Health Study. N Engl J Med 1989;32:129135.

18. The Medical Research Council's General Practice Research Framework. Thrombosis prevention trial: randomised trial of low-intensity oral anticoagulation with warfarin and lowdose aspirin in the primary prevention of ischaemic heart disease in men at increased risk. Lancet 1998;351:233-241.

19. Hansson L, Zanchetti A, Carruthers SG, Dahlöf B, Elmfeldt D, Julius S, Ménard J, Rahn KH, Wedel H, Westerling S. Effects of intensive blood-pressure lowering and low-dose aspirin in patients with hypertension: principal results of the Hypertension Optimal Treatment (HOT) randomised trial. HOT Study Group. Lancet 1998;351:1755-1762.

20. de Gaetano G; Collaborative Group of the Primary Prevention Project. Low-dose aspirin and vitamin E in people at cardiovascular risk: a randomised trial in general practice. Lancet 2001;357:89-95.

21. Ridker PM, Cook NR, Lee IM, Gordon D, Gaziano JM, Manson JE, Hennekens $\mathrm{CH}$, Buring JE. A randomized trial of low-dose aspirin in the primary prevention of cardiovascular disease in women. N Engl J Med 2005;352:1293-1304.

22. Belch J, MacCuish A, Campbell I, Cobbe S, Taylor R, Prescott R, Lee R, Bancroft J, MacEwan S, Shepher J, Macfarlane P, Morris A, Jung R, Kelly C, Connacher A, Peden N, Jamieson A, Matthews D, Leese G, McKnight J, O’Brien I, Semple C, Petrie J, Gordon D, Pringle S, MacWalter R; Prevention of Progression of Arterial Disease and Diabetes Study Group; Diabetes Registry Group; Royal College of Physicians Ediburgh. The prevention of progression of arterial disease and diabetes (POPADAD) trial: factorial randomised placebo controlled trial of aspirin and antioxidants in patients with diabetes and asymptomatic peripheral arterial disease. BMJ 2008;337:a1840.

23. Ogawa H, Makayama M, Morimoto T, Uemura S, Kanauchi M, Doi N, Jinnouchi H, Sugiyama S, Saito Y; Japanese Primary Prevention of Atherosclerosis With Aspirin for Diabetes (JPAD) Trial Investigators. Low-dose aspirin for primary prevention of atherosclerotic events in patients with type 2 diabetes: a randomized controlled trial. JAMA 2008;300:2134-2141.
24. Fowkes FG, Price JF, Stewart MC, Butcher I, Leng GC, Pell AC, Sandercock PA, Fox KA, Lowe GD, Murray GD; Aspirin for Asymptomatic Atherosclerosis Trialists. Aspirin for prevention of cardiovascular events in a general population screened for a low ankle brachial index: a randomized controlled trial. JAMA 2010;303:841-848.

25. Bartolucci AA, Tendera M, Howard G. Meta-analysis of multiple primary prevention trials of cardiovascular events using aspirin. Am J Cardiol 2011;107:1796-1801.

26. Berger JS, Lala A, Krantz MJ, Baker GS, Hiatt WR. Aspirin for the prevention of cardiovascular events in patients without clinical cardiovascular disease: a meta-analysis of randomized trials. Am Heart J 2011;162:115-124.

27. Seshasai SR, Wijesurjya S, Sivakumaran R, Nethercott S, Ergou S, Sattar N, Ray KK. Effect of aspirin on vascular and nonvascular outcomes: meta-analysis of randomized controlled trials. Arch Intern Med 2012;172:209-216.

28. Antithrombotic Trialists' (ATT) Collaboration, Baigent C, Blackwell L, Collins R, Emberson J, Godwin J, Peto R, Buring J, Hennekens C, Kearney P, Meade T, Patrono C, Roncaglioni $\mathrm{MC}$, Zanchetti A. Aspirin in the primary and secondary prevention of vascular disease: collaborative metaanalysis of individual participant data from randomised trials. Lancet 2009;373:1849-1860.

29. Chan FK, Chung SC, Suen BY, Lee YT, Leung WK, Leung VK, Wu JC, Lau JY, Hui Y, Lai MS, Chan HL, Sung JJ. Preventing recurrent upper gastrointestinal bleeding in patients with Helicobacter pylori infection who are taking low-dose aspirin or naproxen. N Engl J Med 2001;344:967973.

30. García Rodríguez LA, Ruigómez A. Secondary prevention of upper gastrointestinal bleeding associated with maintenance acid-suppressing treatment in patients with peptic ulcer bleed. Epidemiology 1999;10:228-232.

31. Lai KC, Lam SK, Chu KM, Wong BC, Hui WM, Hu WH, Lau GK, Wong WM, Yuen MF, Chan AO, Lai CL, Wong J. Lasoprazole for the prevention of recurrences of ulcer complications from long-term low-dose aspirin use. N Engl J Med 2002;346:2033-2038.

32. Lanza FL, Chan FK, Quigley EM; Practice Parameters Committee of the American College of Gastroenterology. Guidelines for prevention of NSAID-related ulcer complications. Am J Gastroenterol 2009;104:728-738.

33. Barkun AN, Bardou M, Kuipers EJ, Sung J, Hunt RH, Martel M, Sinclair P; International Consensus Upper Gastrointestinal Bleeding Conference Group. International consensus recommendations on the management of patients with nonvariceal upper gastrointestinal bleeding. Ann Intern Med 2010;152:101-113.

34. Chan FK, CHing JY, Hung LC, Wong VW, Leung VK, Kung NN, Hui AJ, Wu JC, Leung WK, Lee VW, Lee KK, Lee YT, Lau JY, To KF, Chan HL, Chung SC, Sung JJ. Clopidogrel versus aspirin and esomeprazole to prevent recurrent ulcer bleeding. N Engl J Med 2005;352:238-244.

35. Lai KC, Chu KM, Hui WM, Wong BC, Hung WK, Loo CK, $\mathrm{Hu}$ WH, Chan AO, Kwok KF, Fung TT, Wong J, Lam SK. Esomeprazole with aspirin versus clopidogrel for prevention of recurrent gastrointestinal ulcer complications. Clin Gastroenterol Hepatol 2006;4:860865.

36. Brighton TA, Eikelboom JW, Mann K, Mister R, Gallus A, Ockelford P, Gibbs H, Hague W, Xavier D, Diaz R, Kirby A, Simes J; ASPIRE Investigators. Low-dose aspirin for preventing recurrent venous thromboembolism. N Engl J Med 2012;367:1979-1987.

37. Berger JS, Roncaglioni MC, Avanzini F, Pangrazzi I, Tognoni $\mathrm{G}$, Brown DL. Aspirin for the primary prevention of cardiovascular events in women and men: a sex-specific meta-analysis of randomized controlled trials. JAMA 2006;295:306-313. 
38. Quayym R, Becker DM, Yanek LR, Moy TF, Becker LC, Faraday N, Vaidya D. Platelet inhibition by aspirin 81 and $325 \mathrm{mg} /$ day in men versus women without clinically apparent cardiovascular disease. Am J Cardiol 2008;101:1359-1363.

39. Pignone M, Alberts MJ, Colwell JA, Cushman M, Inzucchi SE, Mukherjee D, Rosenson RS, Williams CD, Wilson PW, Kirkman MS. Aspirin for primary prevention of cardiovascular events in people with diabetes: a position statement of the American Diabetes Association, a scientific statement of the American Heart Association, and an expert consensus document of the American College of Cardiology Foundation. Circulation 2010;121:2694-2701.

40. Early Treatment Diabetic Retinopathy Study design and baseline patient characteristics. ETDRS report number 7 . Opthamology 1991;98:741-756.

41. Aspirin effects on mortality and morbidity in patients with diabetes mellitus. Early Treatment Diabetic Retinopathy Study report 14. ETDRS Investigators. JAMA 1992;268:1292-1300.

42. Buse JB, Ginsberg HN, Bakris GL, Clark NG, Costa F, Eckel R, Fonseca V, Gerstein HC, Grundy S, Nesto RW, Pignone MP, Plutzk J, Porte D, Redberg R, Stitzel KF, Stone NJ; American Heart Association; American Diabetes Association. Primary prevention of cardiovascular diseases in people with diabetes mellitus: a scientific statement from the American Heart Association and the American Diabetes Association. Circulation 2007;115:114-126.

43. Zhang C, Sun A, Zhang P, Wu C, Zhang S, Fu M, Wang K, Zou Y, Ge J. Aspirin for primary prevention of cardiovascular events in patients with diabetes: A meta-analysis. Diabetes Res Clin Pract 2010;87:211-218.

44. Nelson M, Reid C, Beilin L, Donnan G, Johnston C, Krum H, Storey E, Tonkin A, McNeil J; Aspirin in Reducing Events in the Elderly (ASPREE) Study Group. Rationale for a trial of low-dose aspirin for the primary prevention of major adverse cardiovascular events and vascular dementia in the elderly: Aspirin in Reducing Events in the Elderly (ASPREE). Drugs Aging 2003;20:897-903.

45. De Berardis G, Sacco M, Evangelista V, Filippi A, Giorda CB, Tognoni G, Valentini U, Nicolucci Al; ACCEPT-D Study Group. Aspirin and Simvastatin Combination for Cardiovascular Events Prevention Trial in Diabetes (ACCEPT-D): design of a randomized study of the efficacy of low-dose aspirin in the prevention of cardiovascular events in subjects with diabetes mellitus treated with statins. Trials 2007;8:21.

46. ASCEND Trial Website. A Study of Cardiovascular Events iN Diabetes (ASCEND). British Heart Foundation and University of Oxford Clinical Trial Service Unit. Available at: http://www.ctsu.ac.uk/ascend. Accessed March 13, 2013.

47. ARRIVE Study Website. Aspirin to Reduce Risk of Initial Vascular Events (ARRIVE). Bayer HealthCare. Available at: http://www.arrive-study.com/EN/study.cfm. Accessed July 15, 2013.

48. Goldstein LB, Bushnell CD, Adams RJ, Appel LJ, Braun LT, Chaturvedi S, Creager MA, Culebras A, Exkel RH, Hart RG, Hinchey JA, Howard VJ, Jauch EC, Levine SR, Meschia JF, Moore WS, Nixon JV, Pearson TA; American Heart Association Stroke Council; Council on Cardiovascular Nursing; Council on Epidemiology and Prevention; Council for High Blood Pressure Research; Council on Peripheral Vascular Disease, and Interdisciplinary Council on Quality of Care Outcomes Research. Guidelines for the primary prevention of stroke: a guideline for healthcare professionals from the American Heart Association/American Stroke Association. Stroke 2011;42:517-584.
49. Metheny M, McPheeters ML, Glasser A, Mercaldo N, Weaver RB, Jerome RN, Walden R, McKoy JN, Pritchett J, Tsai C. Systematic review of cardiovascular disease risk assessment tools. Evidence Synthesis No. 85. AHRQ Publication No. 11-05155-EF-1. Rockville, MD: Agency for Healthcare Research and Quality; 2011.

50. Anderson KM, Odell PM, Wilson PW, Kannel WB. Cardiovascular disease risk profiles. Am Heart J 1991;121:293-298.

51. Conroy RM, Pyörälä K, Fitzgerald AP, Sans S, Menotti A, De Backer G, De Bacquer D, Ducimetière P, Jousilahti P, Keil U, Oganov RG, Thomsen T, Tunstall-Pedoe H, Tverdal A, Wedel H, Whincup P, Wilhelmsen L, Graham IM; SCORE project group. Estimation of ten-year risk of fatal cardiovascular disease in Europe: the SCORE project. Eur Heart J 2003;24:987-1003.

52. Nishihara R, Lochhead P, Kuchiba A, Jung S, Yamauchi M, Liao X, Imamura Y, Qian ZR, Morikawa T, Wang M, Spiefelman D, Cho E, Giovannucci E, Fuchs CS, Chan AT, Ogino S. Aspirin use and risk of colorectal cancer according to BRAF mutation status. JAMA 2013;309:2563-2571.

53. Pignone M, Anderson GK, Binns K, Tilson HH, Weisman SM. Aspirin use among adults aged 40 and older in the United States: results of a national survey. Am J Prev Med 2007;32:403-407.

\section{Author Affiliations}

Sunitha V. Ittaman, $M D^{*}$; Jeffrey J. VanWormer, PhD'; Shereif H. Rezkalla, $M D^{t}$

\author{
*Department of Internal Medicine, Marshfield Clinic, \\ Marshfield, WI USA \\ Epidemiology Research Center, Marshfield Clinic Research \\ Foundation, Marshfield, WI USA \\ ${ }^{*}$ Department of Cardiology, Marshfield Clinic, Marshfield, \\ WI USA
}

